\title{
OPTIMASI PROSES MI JAGUNG VARIETAS LOKAL DENGAN TEKNOLOGI EKSTRUSI
}

\section{[Optimization of Local Maize Noodles Processing using Extrusion Technology]}

\author{
Atiqatul Maula ${ }^{1)}$, Didah Nur Faridah ${ }^{2,3) \star}$, dan Tjahja Muhandri ${ }^{2,3)}$ \\ 1) Program Studi Ilmu Pangan, Sekolah Pascasarjana, Institut Pertanian Bogor, Bogor \\ 2) Departemen Ilmu dan Teknologi Pangan, Fakultas Teknologi Pertanian, Institut Pertanian Bogor, Bogor \\ 3) Southeast Asian Food and Agricultural Science and Technology (SEAFAST) Center, Institut Pertanian Bogor, Bogor
}

Diterima 25 Agustus 2018 / Disetujui 26 April 2019

\begin{abstract}
Maize noodles processing is different from that of conventional noodles made of wheat flour. In producing non wheat (gluten free) noodles, engineering is needed in the manufacturing process to obtain noodles with good quality and similar to the physical quality of wheat noodles. Processing of maize noodles requires particular treatment, such as heating, shearing, and maize noodles processing with sheeting techniques had previously been reported. Maize noodles processing using extrusion technology has also been done, but in previous studies, the maize used was of the hybrid varieties. This study aims to identify the pasting properties of maize flour and optimize the processing of dried maize noodles from local variety obtained from Madura Island named Elos. Extrusion technology was used to produce maize noodles with good physical characteristics. This study used a cooking-forming single screw extruder and formula consisting of $100 \%$ maize flour (db), $70 \%$ moisture content, and $2 \% \mathrm{NaCl}$. The experimental design was a complete randomized factorial design with two process variables, i.e. extruder temperature setting $\left(75,90\right.$, and $\left.105^{\circ} \mathrm{C}\right)$ and extruder screw speed setting $(100,130$, and $160 \mathrm{rpm})$. Response surface methodology (RSM) was used for process optimization to obtain the best process conditions based on several physical characteristics as the responses, i.e. cooking loss, elongation, hardness and degree of gelatinization. The optimum process conditions resulted from the Design Expert 7.0 program were extruder temperature of $95^{\circ} \mathrm{C}$ and screw speed of $100 \mathrm{rpm}$. The optimum condition produced maize noodles with cooking loss of $10.11 \%$, elongation of $156.73 \%$, hardness of $6252 \mathrm{gf}$ and degree of gelatinization of $92.26 \%$, with a desirability value of 0.954 .
\end{abstract}

Keywords: Elos maize, extrusion, noodles, optimization

\begin{abstract}
ABSTRAK
Pembuatan mi jagung berbeda dengan pembuatan mi dari tepung terigu. Pada pembuatan mi berbahan baku non terigu diperlukan rekayasa pada proses pembuatannya untuk mendapatkan hasil mi yang baik dan mendekati mutu fisik mi terigu. Pembuatan mi jagung membutuhkan proses pemanasan, shearing dan air yang cukup untuk memperoleh mi dengan mutu fisik yang baik. Pembuatan mi jagung dengan teknik sheeting sebelumnya pernah dilakukan. Pembuatan mi jagung dengan teknologi ekstrusi juga pernah dilakukan tetapi menggunakan jagung varietas hibrida. Penelitian ini bertujuan mengidentifikasi pasting properties dan melakukan optimasi proses dengan dua faktor yaitu suhu dan kecepatan screw ekstruder pada pembuatan mi dari tepung jagung varietas lokal Madura (Elos) dengan teknologi ekstrusi untuk menghasilkan mi jagung dengan karakteristik fisik yang baik. Ekstruder yang digunakan adalah cooking-forming single screw extruder dengan formula 100\% tepung jagung, $70 \%$ air dan $2 \%$ garam. Rancangan percobaan yang digunakan adalah Rancangan Acak Lengkap Faktorial dengan dua variabel proses yaitu: suhu ektruder $\left(75,90\right.$, dan $\left.105^{\circ} \mathrm{C}\right)$ dan kecepatan screw ekstruder (100, 130 dan $\left.160 \mathrm{rpm}\right)$. Mi jagung dikeringkan menggunakan tray drier pada suhu ruang selama 24 jam. Sifat fisik mi yang digunakan sebagai respon antara lain: cooking loss, elongasi, kekerasan dan derajat gelatinisasi. Kondisi proses optimum yang diperoleh menggunakan software Design Expert 7.0 adalah pada suhu $95^{\circ} \mathrm{C}$ dan kecepatan screw ekstruder $100 \mathrm{rpm}$. Kondisi optimum menghasilkan mi jagung dengan sifat fisik cooking loss $10,11 \%$, elongasi $156,73 \%$, kekerasan 6252 gf dan derajat gelatinisasi $92,26 \%$, serta nilai desirability sebesar 0,954.
\end{abstract}

Kata kunci: ekstrusi, jagung Elos, mi, optimasi

\footnotetext{
*Penulis Korespondensi:

Email: didah_nf@apps.ac.id
} 


\section{PENDAHULUAN}

Pembuatan mi berbahan dasar tepung jagung berbeda dengan mi berbahan dasar tepung terigu karena perbedaan karakteristik kedua tepung tersebut. Pembuatan mi berbahan jagung sebelumnya telah dilakukan menggunakan teknik sheeting oleh Kusnandar et al. (2009) dengan substitusi tepung jagung modifikasi heat moisture treatment (HMT) $40 \%$ dan menghasilkan mi jagung dengan mutu fisik yang baik, dan dilakukan oleh Indrianti et al. (2014) menggunakan teknik sheeting-slitting berbahan baku tepung jagung 60 mesh. Pada pembuatan mi berbahan baku non terigu diperlukan rekayasa pada proses pembuatannya dikarenakan tidak adanya gluten yang dapat membentuk adonan mi menjadi elastis. Penambahan bahan juga dapat dilakukan untuk mendapatkan hasil mi dengan mutu fisik yang mendekati mi terigu. Salah satu teknologi yang dapat digunakan dalam pembuatan mi non gluten adalah teknologi ekstrusi karena telah menggabungkan beberapa proses sekaligus seperti pencampuran, shearing, pemanasan dan pembentukan atau pencetakan sehingga lebih efektif. Muhandri et al. (2009) menyatakan bahwa pembuatan mi jagung dipengaruhi oleh adanya pemanasan, shearing dan kadar air yang cukup untuk mendapatkan mutu fisik mi yang baik.

Pembuatan mi non terigu dengan bahan baku tepung jagung telah dilakukan sebelumnya dengan teknologi ekstrusi menggunakan cooking-forming single screw extruder dengan kondisi optimum hasil optimasi menggunakan response surface methodlogy (RSM) pada suhu ekstruder $90^{\circ} \mathrm{C}$, kadar air $70 \%$ dan kecepatan screw 130 rpm. Mi jagung basah varietas hibrida Pioneer 21 (P21) yang dihasilkan memiliki karakteristik yang baik secara fisik (elongasi, cooking loss, kekerasan dan kelengketan) (Muhandri et al., 2011). Mi jagung kering dengan teknologi ekstrusi dan formula penambahan glycerol mono-stearate (GMS) yang dapat diterima secara organoleptik (Subarna et al., 2012).

Kondisi optimum proses pada penelitian Muhandri et al. (2011) tidak secara langsung dapat diterapkan pada tepung jagung varietas lain termasuk varietas lokal karena kondisi proses seperti suhu dan kecepatan screw ekstrusi pembuatan mi jagung dipengaruhi oleh pasting properties tepung yang digunakan. Informasi mengenai pasting properties suatu bahan yang akan digunakan dalam proses pembuatan mi dengan teknologi ekstrusi perlu diketahui. Tam et al. (2004) mengelompokkan jenis-jenis pati jagung yang dapat diproses menjadi mi bihun dengan teknologi ekstrusi berdasarkan pasting properties. Jenis pati yang baik digunakan sebagai bahan mi bihun dengan teknologi ekstrusi adalah pati normal. Pati normal memiliki viskositas pasta dingin yang tinggi dan menunjukkan kecen- derungan retrogradasi yang cepat sehingga cocok sebagai bahan mi bihun dengan teknologi ekstrusi.

Muhandri et al. (2012) telah meneliti penggunaan jagung varietas lokal (Bisma, Sukamaraga, Lamuru, Srikandi, Arjuna) untuk pembuatan mi jagung dengan menggunakan ekstruder pasta (yang tidak dilengkapi pemanas). Hasil penelitian menunjukkan bahwa varietas dengan kisaran kadar amilosa $23,06-27,26 \%$ mampu menghasilkan mi dengan karakteristik elongasi cukup tinggi berkisar 58,70$95,43 \%$. Penggunaan ekstruder pemasak-pencetak (dilengkapi pemanas) untuk pembuatan mi jagung berbahan tepung varietas lokal Elos (asal Madura) belum dilakukan.

Tujuan penelitian ini adalah untuk mengetahui karakteristik (pasting properties) tepung jagung varietas lokal Elos, mengetahui pengaruh suhu dan kecepatan screw ekstruder terhadap mutu fisik mi jagung dengan teknologi ekstrusi pemasak-pencetak ulir tunggal, serta menentukan perlakuan ekstrusi terbaik pada pebuatan mi jagung Elos dengan optimasi proses menggunakan RSM.

\section{BAHAN DAN METODE}

\section{Bahan}

Bahan utama yang digunakan dalam penelitian ini adalah jagung kuning pipil varietas lokal Elos dari Kabupaten Pamekasan, Jawa Timur, air, garam dapur $(\mathrm{NaCl})$, dan akuades.

\section{Persiapan tepung jagung}

Jagung Elos yang sudah dipipil digiling hingga menjadi grits menggunakan Pin Disc Mill (Multi-mill Gansons Limited Bombay-55, SR.NO. 1452, India) dengan saringan 7 mesh. Bagian luar jagung seperti tip cap, lembaga dan kulit air dipisahkan dengan cara pengambangan dan pencucian sebanyak 5 kali lalu ditiriskan. Grits jagung dikeringkan selama \pm 1 jam hingga mencapai kadar air sekitar $35 \pm 2 \%$. Grits jagung digiling lagi menggunakan Pin Disc Mill (Multi mill Gansons Limited Bombay-55, India) dengan saringan 48 mesh. Tepung jagung yang masih kasar dikeringkan di dalam cabinet dryer (Pilot Plant Engineering \& Equipment $\mathrm{GmbH} 6072$ Dreieich, type ITHU, West Germany) pada suhu $50^{\circ} \mathrm{C}$ selama \pm 16 jam kemudian diayak menggunakan vibrating screen machine (Dalal Engineering PVT. LTD. Thana, under licence from William Boulton LTD. model GGCMS. 107 Dry, England) saringan 80 mesh. Tepung jagung dihomogenisasi menggunakan dough mixer (Planetary mixer Gansons Limited Bombay55, PLM 50 serial no. 172, India) selama 15 menit kemudian dikemas dalam alumunium foil per $1 \mathrm{~kg}$ dan disimpan dalam Freezer $\left(-4^{\circ} \mathrm{C}\right)$ hingga tepung jagung digunakan. 


\section{Pembuatan mi jagung}

Tahap ini dilakukan dengan membuat mi jagung yang mengacu pada Muhandri et al. (2011), yaitu dengan tahapan pencampuran tepung jagung (100\%), air (70\%) dan garam (2\%) menggunakan hand mixer (Philips Hand Mixer HR-1538, Malaysia) selama 5 menit, adonan dimasukkan ke dalam ekstruder (cooking-forming extruder model Scientific Laboratory Single Screw Extruder type LE25-30/C dari Labtech Engineering Co. Ltd., Thailand), untaian mi dipotong $\pm 50 \mathrm{~cm}$ kemudian mi dikeringkan menggunakan tray dryer pada suhu ruang selama 24 jam.

\section{Sifat fisikokimia jagung}

Analisis tepung jagung meliputi analisis proksimat (AOAC, 2005), analisis kadar amilosa (Faridah et al., 2014), dan analisis profil gelatinisasi (pasting properties) menggunakan rapid visco analyzer (RVA) (Kesarwani et al., 2016).

\section{Analisis kehilangan padatan selama pemasakan (Kongkiattisak dan Songsermpong 2012, dengan modifikasi)}

Penentuan kehilangan selama pemasakan (cooking loss) dilakukan mengikuti Kongkiattisak dan Songsermpong (2012), Pada penelitian ini dilakukan sedikit modifikasi yaitu mi ditimbang $\pm 5 \mathrm{~g} \mathrm{mi}$ kering (tanpa dipotong-potong) dalam $150 \mathrm{~mL}$ air. $\mathrm{Mi}$ jagung direbus selama 10 menit, ditiriskan dan disiram air, kemudian ditiriskan kembali selama 5 menit. Mi kemudian ditimbang dan dikeringkan pada suhu $100^{\circ} \mathrm{C}$ sampai beratnya konstan, kemudian ditimbang kembali. Disamping itu dilakukan juga pengukuran kadar air pada sampel sebanyak $5 \mathrm{~g}$. Pengukuran kadar air dilakukan untuk menghitung berat kering sampel. Cooking loss dihitung dengan rumus berikut:

$$
\text { Cooking Loss }=\frac{\mathrm{A}-\mathrm{B}}{\mathrm{A}} \times 100 \% \text {. }
$$

dimana, $A$ adalah berat kering sampel sebelum direbus $(\mathrm{g})$ dan $\mathrm{B}$ adalah berat kering sampel sesudah direbus $(\mathrm{g})$.

\section{Analisis elongasi menggunakan texture analyzer (Subarna et al., 2012)}

Analisis elongasi dilakukan menggunakan instrumen Texture Analyzer Stable Micro-System TA$\mathrm{XT2i}$, England. Analisis dilakukan terhadap sampel mi jagung yang telah dimasak selama 10 menit. Analisis dilakukan dengan melilitkan satu untaian mi pada probe dengan jarak antar probe $2 \mathrm{~cm}$ dan kecepatan probe $0,3 \mathrm{~cm} / \mathrm{s}$. Presentase elongasi dapat dihitung dengan cara:

$$
\begin{aligned}
& \text { Percentage of Elongation }= \\
& \frac{\text { time of sampel broken off }(\mathrm{s}) \times 0,3 \mathrm{~cm} / \mathrm{s}}{2 \mathrm{~cm}} \times 100 \%
\end{aligned}
$$

\section{Analisis kekerasan menggunakan texture analy- zer (Muhandri et al., 2011)}

Analisis untuk memperoleh data kekerasan mi digunakan probe berbentuk silinder dengan diameter $35 \mathrm{~mm}$. Probe silinder dipilih karena sesuai dengan produk yang dianalisis yaitu agar dapat menekan seluruh permukaan mi secara merata. Pengukuran dilakukan dengan meletakkan dua untai mi di atas papan kompresi lalu ditekan oleh probe. Pengaturan mode untuk pengukuran TPA adalah pre test speed $2.0 \mathrm{~mm} / \mathrm{s}$, test speed $1.0 \mathrm{~mm} / \mathrm{s}$, post test speed $2.0 \mathrm{~mm} / \mathrm{s}$ dan rupture test distance $75 \%$.

\section{Analisis derajat gelatinisasi (Budi et al., 2015)}

Derajat gelatinisasi mi jagung dianalisis dengan menggunakan metode miroskop cahaya terpolarisasi. Langkah pertama adalah pembuatan kurva standar hubungan derajat gelatinisasi dan konsentrasi granula. Suspensi pati atau tepung native $1 \%$ dan suspensi pati $1 \%$ yang tergelatinisasi sempurna dibuat dan dicampur untuk memperoleh suspensi standar dengan derajat gelatinisasi $0,20,40,60,80$ dan $100 \%$. Kemudian suspensi standar ini diteteskan ke atas hemocytometer dengan micropipette dan diamati di bawah cahaya terpolarisasi dengan perbesaran 200x pada mikroskop Olympus B071, Japan. Jumlah granula pati yang masih sempurna dihitung untuk memperoleh konsentrasi granula yang masih sempurna dengan persamaan berikut:

Konsentrasi Granula $=\frac{\text { jumlah granula }}{\text { volume }(\mathrm{mL})}$

Volume yang dimaksud dalam persamaan tersebut merupakan volume satu bidang kotak pada kaca hemocytometer yang mempunyai luas 0,0625 $\mathrm{mm}^{2}$ dan kedalaman $0,1 \mathrm{~mm}$. Sehingga volume satu bidang kotak tersebut adalah $(0,0625 \times 0,1) \mathrm{m}^{3}$ atau $0,00625 \mathrm{~mL}$.

Langkah kedua adalah menganalisis konsentrasi granula di dalam sampel. Sampel yang telah dihaluskan disuspensikan ke dalam air untuk mendapatkan konsentrasi $1 \%$ dan diteteskan ke atas kaca hemocytometer untuk dilihat di bawah cahaya terpolarisasi dengan perbesaran 200x pada mikroskop Olympus. Konsentrasi granula yang masih sempurna dihitung dan diplotkan ke kurva standar untuk memperoleh derajat gelatinisasi.

\section{Rancangan percobaan dan analisis data}

Rancangan percobaan yang digunakan adalah rancangan acak lengkap faktorial yang terdiri dari dua faktor dan tiga taraf pada masing-masing faktor. 
Faktor yang digunakan adalah faktor suhu ekstruder $\left(75,90\right.$ dan $\left.105^{\circ} \mathrm{C}\right)$ dan faktor kecepatan screw ekstruder (100, 130 dan 160 rpm). Berdasarkan rancangan percobaan tersebut terdapat sembilan perlakuan yang dilakukan masing-masing dua kali ulangan (batch) yang kemudian dianalisis dengan dua kali ulangan (duplo) pada setiap analisis. Delapan belas sampel tersebut dianalisis berdasarkan parameter cooking loss, elongasi, kekerasan dan derajat gelatinisasi. Data hasil analisis dihitung menggunakan microsoft excel, sedangkan analisis pengaruh suhu ekstruder dan kecepatan ulir terhadap mutu fisik mi jagung dilakukan dengan menggunakan software XLSTAT 2016 ANOVA dengan uji lanjut Duncan pada taraf uji $P<0,05$ dan microsot excel.

Hasil rata-rata dari kedelapan belas sampel dari keempat parameter kemudian dianalisis menggunakan response surface methodology (RSM) untuk memperoleh perlakuan yang paling optimum (optimal) berdasarkan empat parameter yang telah disebutkan. Analisis optimasi proses menggunakan RSM Historical Data dengan Design Expert 7.0. Respon yang paling optimum diperoleh jika nilai desirability mendekati 1 . Setiap respon yang dioptimasi diberikan bobot kepentingan berdasarkan tujuan yang ingin dicapai. Pemilihan pembobotan kepentingan (importance) ini dapat dilakukan mulai dari $1(+)$ hingga $5(++++)$ sesuai kepentingan variabel respon. Semakin banyak tanda positif yang diberikan berarti bahwa tingkat kepentingan respon tersebut semakin tinggi. Analisis dengan RSM ini untuk menentukan proses optimum dalam pembuatan $\mathrm{mi}$ jagung varietas Elos yaitu dengan nilai cooking loss yang rendah, tekstur mi yang baik dan tidak mudah putus. Hasil kondisi proses optimum diverifikasi dengan perlakuan pembuatan mi jagung dan analisis fisik.

\section{HASIL DAN PEMBAHASAN}

\section{Karakteristik tepung jagung Elos}

Hasil analisis proksimat dan kadar amilosa tepung jagung varietas lokal Elos (80 mesh) dibandingkan dengan tepung jagung varietas hibrida Pioneer 21 (Muhandri et al., 2009) dan nilai pati jagung (Budi et al., 2015) pada Tabel 1. Kandungan amilosa tepung jagung Elos diketahui lebih rendah yiatu $27,89 \%$ dibandingkan dengan kadar amilosa jagung hibrida P21 yang sebesar 30,09\% (Muhandri et al., 2009) dan kadar amilosa pati jagung yang sebesar 38,29\% (Budi et al., 2015). Tam et al. (2004) menggolongkan pati jagung berdasarkan kadar amilosanya menjadi tiga kelompok yaitu kadar amilosa sedang (normal) $(27,6-28,8 \%)$, amilosa rendah $(0,2-3,8 \%)$ dan amilosa tinggi $(40-60,8 \%)$. Jika berdasarkan klasifikasi tersebut, kadar amilosa tepung jagung Elos lebih mendekati kadar amilosa se- dang (normal), kemudian Tam et al. (2004) juga menyatakan bahwa pati jagung dengan kadar amilosa normal memiliki karakteristik yang baik sebagai bahan pembuatan mi dengan teknologi ekstrusi.

Tabel 1. Analisis proksimat dan kadar amilosa tepung jagung dan pati jagung

\begin{tabular}{lccc}
\hline $\begin{array}{c}\text { Parameter } \\
(\%)\end{array}$ & $\begin{array}{c}\text { Tepung } \\
\text { Jagung } \\
\text { Elos }\end{array}$ & $\begin{array}{c}\text { Tepung } \\
\text { Jagung } \\
\text { Hibrida } \\
\text { P21* }\end{array}$ & $\begin{array}{c}\text { Pati } \\
\text { Jagung }\end{array}$ \\
\hline Air & $9,40 \pm 0,18$ & 5,46 & $12,03 \pm 0,05$ \\
Abu & $0,66 \pm 0,03$ & 0,31 & $0,09 \pm 0,01$ \\
Lemak & $1,97 \pm 0,18$ & 1,73 & $0,19 \pm 0,02$ \\
Protein & $6,98 \pm 0,08$ & 6,32 & $0,45 \pm 0,02$ \\
Karbohidrat & $80,97 \pm 0,44$ & 86,18 & $87,22 \pm 0,03$ \\
Amilosa & $27,89 \pm 0,25$ & 30,09 & $38,29 \pm 0,34$ \\
\hline Keterangan: ${ }^{*}$ Sumber:
\end{tabular}

Keterangan: *Sumber: Muhandri et al., 2009; ${ }^{* *}$ Sumber: Budi et al., 2015

Karakteristik sifat gelatinisasi (pasting properties) tepung jagung Elos menggunakan RVA ditunjukkan pada Tabel 2. Suhu awal gelatinisasi tepung jagung Elos pada suhu $73,55^{\circ} \mathrm{C}$. Suhu awal gelatinisasi tersebut lebih tinggi dibandingkan dengan suhu awal gelatinisasi tepung jagung (80 mesh) varietas hibrida P21 yaitu $72^{\circ} \mathrm{C}$, dan memiliki suhu gelatinisasi maksimum $91,05^{\circ} \mathrm{C}$ yang lebih rendah dari suhu awal gelatinisasi maksimum tepung jagung hibrida P21 yang sebesar $93^{\circ} \mathrm{C}$ (Muhandri et al., 2011).

Tabel 2. Karakteristik gelatinisasi tepung jagung Elos

\begin{tabular}{lc}
\hline \multicolumn{1}{c}{ Parameter } & Nilai \\
\hline Suhu awal gelatinisasi $\left({ }^{\circ} \mathrm{C}\right)$ & $73,55 \pm 0,14$ \\
Suhu gelatinisasi maksimum $\left({ }^{\circ} \mathrm{C}\right)$ & $91,05 \pm 0,57$ \\
Viskositas maksimum $(\mathrm{cP})$ & $3062,50 \pm 74,25$ \\
Viskositas breakdown $(\mathrm{cP})$ & $1380,00 \pm 1,41$ \\
Viskositas setback $(\mathrm{cP})$ & $2776,50 \pm 3,54$ \\
Viskositas akhir $(\mathrm{cP})$ & $4459,00 \pm 2,12$ \\
\hline
\end{tabular}

Suhu awal gelatinisasi adalah suhu ketika perubahan fisik pada granula pati mulai terdeteksi yaitu granula pati mulai mengembang dan amilosa mulai keluar dari granula (Liu, 2005). Informasi suhu awal gelatinisasi ini penting untuk diketahui dalam penentuan rancangan percobaan dengan faktor suhu. Penentuan level terendah pada faktor suhu ekstruder harus lebih tinggi dari suhu awal gelatinisasi (Wang et al., 2014), sehingga panas yang dibutuhkan adonan mi jagung (tepung jagung, air dan garam) cukup untuk dapat tergelatinisasi yang juga dipengaruhi oleh adanya shearing di dalam ekstruder.

\section{Cooking loss mi jagung Elos}

Cooking loos atau biasa juga disebut kehilangan padatan akibat pemasakan (KPAP) didefinisikan sebagai padatan dalam mi yang luruh atau terlarut ke dalam air selama proses pemasakan. Nilai cook- 
ing loss dinyatakan dalam satuan persen (\%) yang merupakan perbandingan berat padatan yang terlepas per berat kering sampel. Cooking loss adalah parameter terpenting untuk produk mi. Semakin rendah nilai cooking loss menunjukkan kualitas mi yang semakin baik. Nilai cooking loss pada mi jagung Elos ditunjukkan pada Gambar 1.

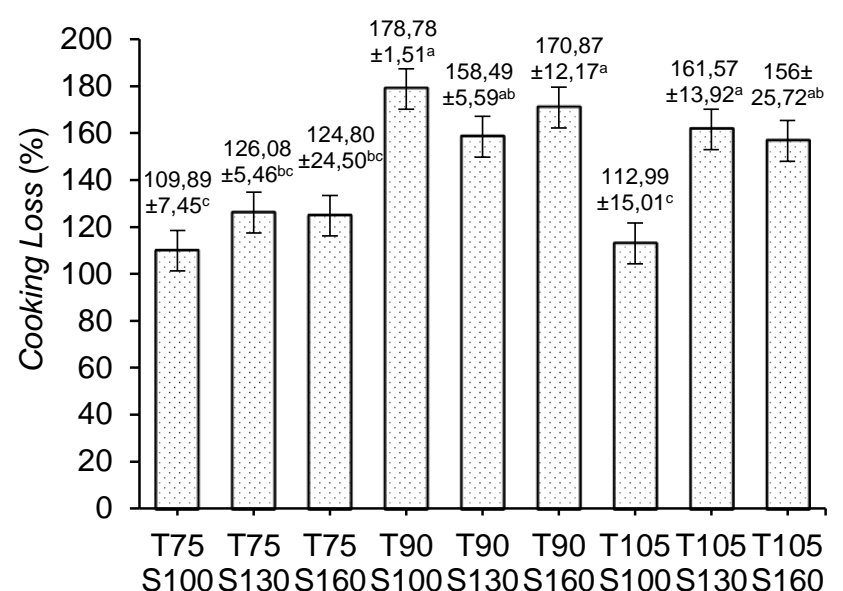

Suhu $\left({ }^{\circ} \mathrm{C}\right)$ Vs. Kecepatan Screw (rpm)

Keterangan: Angka-angka yang diikuti oleh huruf yang berbeda menunjukkan perbedaan yang nyata $(P>0,05)$

\section{Gambar 1. Diagram cooking loss mi jagung Elos}

Variabel suhu ekstruder berpengaruh terhadap respon cooking loss secara signifikan. Suhu yang menunjukkan perbedaan yang nyata adalah suhu $75^{\circ} \mathrm{C} \quad(P<0,05)$, sedangkan variabel kecepatan screw tidak menunjukkan pengaruh yang nyata. Hasil uji lanjut Duncan $(P<0,05)$ menunjukkan bahwa tidak ada pengaruh yang nyata dari interaksi antara variabel suhu dan kecepatan screw ekstruder terhadap nilai respon cooking loss.

Nilai cooking loss paling tinggi adalah pada suhu $75^{\circ} \mathrm{C}$, hal ini diduga karena suhu $75^{\circ} \mathrm{C}$ tidak jauh dari suhu awal gelatinisasi tepung jagung sehingga menyebabkan granula tepung jagung belum tergelatinisasi secara optimum pada suhu tersebut, karena derajat gelatinisasi pada suhu $75^{\circ} \mathrm{C}$ memiliki nilai sekitar $84-87 \%$ dengan adanya shearing stress oleh screw ekstruder pada kecepatan 100-160 rpm. Seiring dengan peningkatan suhu ekstruder pada $90^{\circ} \mathrm{C}$, nilai cooking loss menurun secara signifikan, tetapi peningkatan suhu ektruder hingga suhu $105^{\circ} \mathrm{C}$ tidak menunjukkan penurunan yang signifikan.

Cooking loss disebabkan oleh pati yang tidak tergelatinisasi sempurna sehingga ikatan di permukaan mi lemah dan menjadi larut ketika dimasak (Aydin dan Gocmen, 2011). Hal ini didukung oleh pernyataan Wang et al. (2012) bahwa cooking loss dipengaruhi kekuatan ikatan pati yang tergelatinisasi dan persentase dari pati yang tergelatinisasi.

\section{Elongasi mi jagung Elos}

Elongasi merupakan pertambahan panjang $\mathrm{mi}$ karena adanya gaya tarik dan dinyatakan dalam persen. Sifat elongasi juga merupakan parameter mutu mi yang penting karena menunjukkan karakter mi saat di dalam mulut. Nilai persen elongasi yang tinggi menunjukkan bahwa mi tidak mudah putus. Pengaruh suhu dan kecepatan screw ekstruder terhadap elongasi mi jagung Elos ditunjukkan pada Gambar 2.

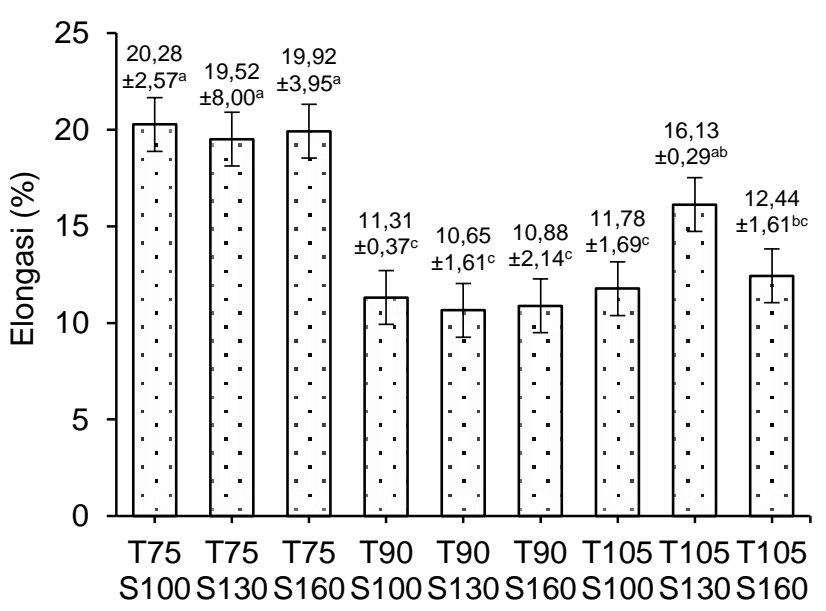

Suhu $\left({ }^{\circ} \mathrm{C}\right)$ Vs. Kecepatan Screw (rpm)

Keterangan: Angka-angka yang diikuti oleh huruf yang berbeda menunjukkan perbedaan yang nyata $(P>0,05)$

\section{Gambar 2. Diagram elongasi pada mi jagung Elos}

Diagram pada Gambar 2 menunjukkan bahwa baik variabel suhu maupun variabel kecepatan screw ekstruder memberikan pengaruh yang signifikan terhadap respon elongasi, serta terdapat interaksi antara kedua variabel tersebut. Hasil uji lanjut Duncan $(P<0,05)$ menunjukkan bahwa suhu ekstruder $90^{\circ} \mathrm{C}$ menunjukkan perbedaan nyata terhadap respon elongasi, sedangkan kecepatan screw ekstruder yang menunjukkan perbedaan nyata adalah pada kecepatan screw 100 rpm. Interaksi antara suhu $90^{\circ} \mathrm{C}$ dan kecepatan screw ekstruder $100 \mathrm{rpm}$ memberikan pengaruh yang signifikan terhadap respon elongasi.

Nilai elongasi tertinggi adalah pada suhu $90^{\circ} \mathrm{C}$, seiring dengan menurunnya suhu ekstruder pada suhu $75^{\circ} \mathrm{C}$, nilai elongasi juga menurun secara signifikan. Nilai elongasi lebih rendah terjadi pada kecepatan screw ekstruder 100 rpm, seiring dengan peningkatan screw ekstruder, nilai elongasi juga cenderung meningkat. Kualitas pemasakan mi terutama dipengaruhi oleh kekuatan ikatan pati yang teretrogradasi. Retrogradasi pati merupakan faktor utama yang dapat membuat tekstur mi yang kuat dan kokoh (Wu et al., 2015). Semakin tinggi suhu dan kecepatan screw ekstruder dapat meningkatkan tekan- 
an dan gelatinisasi pada adonan saat proses ekstrusi yang menyebabkan kekuatan struktur gel semakin tinggi (Tan et al., 2009).

\section{Kekerasan mi jagung Elos}

Kekerasan merupakan sifat suatu makanan yang diukur secara objektif menggunakan alat Texture Analyzer TAXT-2. Nilainya merupakan besar gaya maksimum yang dibutuhkan untuk menekan sampel makanan hingga ketebalan tertentu. Hasil analisis kekerasan mi jagung Elos ditunjukkan pada Gambar 3.

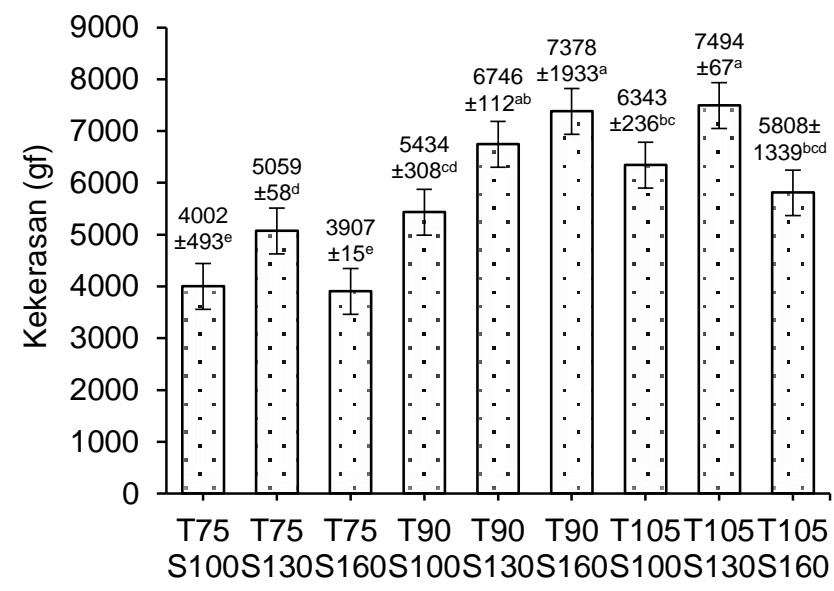

\section{Suhu $\left({ }^{\circ} \mathrm{C}\right)$ Vs. Kecepatan Screw (rpm)}

Keterangan: Angka-angka yang diikuti oleh huruf yang berbeda menunjukkan perbedaan yang nyata $(P>0,05)$

\section{Gambar 3. Diagram kekerasan pada mi jagung Elos}

Hasil analisis kekerasan pada Gambar 3 menunjukkan bahwa kedua variabel berpengaruh nyata terhadap respon kekerasan, serta terdapat pengaruh yang signifikan dari interaksi antara variabel suhu dan kecepatan screw ekstruder terhadap respon kekerasan. Hasil uji lanjut Duncan $(P<0,05)$ menunjukkan bahwa variabel suhu ekstruder yang berbeda nyata adalah suhu $75^{\circ} \mathrm{C}$, sedangkan variabel kecepatan screw ekstruder menunjukkan perbedaan nyata adalah kecepatan screw $130 \mathrm{rpm}$.

Interaksi dua variabel yang menunjukkan nilai kekerasan paling tinggi adalah interaksi antara suhu $90^{\circ} \mathrm{C}$ dan kecepatan screw $160 \mathrm{rpm}$, serta interaksi antara suhu $105^{\circ} \mathrm{C}$ dan kecepatan screw $130 \mathrm{rpm}$, sedangkan nilai kekerasan yang paling rendah terjadi pada suhu $75^{\circ} \mathrm{C}$. Tren ini menunjukkan bahwa seiring peningkatan suhu, nilai kekerasan juga cenderung meningkat. Hal ini sejalan dengan penelitian pada mi basah dari tepung jagung (Muhandri et al., 2011), mi kering dari sagu (Engelen et al., 2015) dan mi kering dari pati kacang kapri (Wang et al., 2012). Wang et al. (2012) juga menyatakan bahwa kekerasan mi semakin tinggi pada suhu barel ekstruder, kecepatan screw dan kadar air adonan mi yang semakin tinggi.

\section{Derajat gelatinisasi mi jagung Elos}

Derajat gelatinisasi diukur menggunakan mikroskop cahaya terpolarisasi yang dilakukan berdasarkan penurunan jumlah granula pati pada bidang hemocytometer dengan empat sudut pandang. Hasil foto mikroskop pada tepung jagung menunjukkan gambar granula pati yang masih terlihat jelas dengan bentuk birefringence yang masih sempurna, sedangkan pada tepung mi jagung yang telah mengalami proses ekstrusi menunjukkan bahwa terjadi perubahan pada bentuk granula patinya, seperti terjadi pembengkakan, pembengkakan dan nampak berlubang-lubang, serta jumlah birefringence yang berkurang atau bahkan tidak nampak. Perubahan bentuk granula pati tersebut mengindikasikan bahwa pati jagung telah tergelatinisasi. Hasil analisis derajat gelatinisasi ditunjukkan pada Gambar 4.

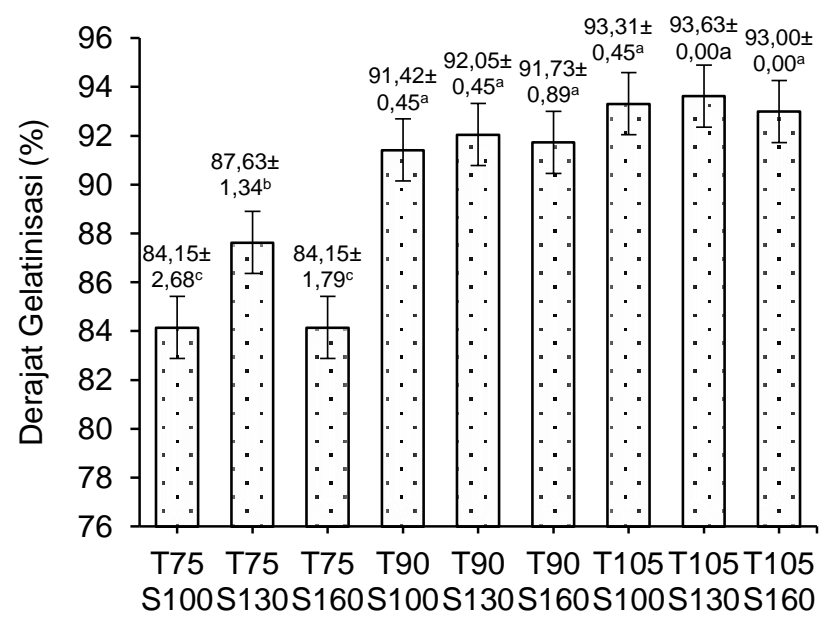

Suhu $\left({ }^{\circ} \mathrm{C}\right)$ Vs. Kecepatan Screw (rpm)

Keterangan: Angka-angka yang diikuti oleh huruf yang berbeda menunjukkan perbedaan yang nyata $(P>0,05)$

Gambar 4. Diagram derajat gelatinisasi mi jagung Elos

Variabel suhu dan kecepatan screw ekstruder memberikan pengaruh signifikan terhadap derajat gelatinisasi, sedangkan interaksi antara kedua variabel suhu dan kecepatan screw tidak menunjukkan pengaruh yang signifikan terhadap respon derajat gelatinisasi. Hasil uji lanjut Duncan $(P<0,05)$ menunjukkan bahwa suhu $75^{\circ} \mathrm{C}$ memiliki perbedaan yang signifikan pada respon derajat gelatinisasi, sedangkan kecepatan screw ekstruder yang menunjukkan perbedaan nyata adalah kecepatan screw $130 \mathrm{rpm}$. Nilai derajat gelatinisasi terendah adalah pada suhu ekstruder $75^{\circ} \mathrm{C}$, hal ini karena suhu $75^{\circ} \mathrm{C}$ hanya sedikit lebih tinggi dari suhu awal gelatinisasi 
tepung jagung Elos sehingga granula pati dalam tepung jagung Elos belum tergelatinisasi dengan baik pada suhu tersebut.

Faktor utama dalam gelatinisasi pati adalah pengembangan granula yang bergantung pada kekuatan, sifat dan jenis ikatan dalam granula. Semakin tinggi suhu ekstruder, nilai derajat gelatinisasi cenderung semakin tinggi. Hal ini didukung oleh pernyataan bahwa energi panas dan mekanik yang ditransfer ke adonan pati selama proses ekstrusi akan memengaruhi perusakan ikatan primer dan sekunder (ikatan hidrogen) antara molekul-molekul pati yang berdekatan di dalam struktur granula pati (Liu et al., 2009).

\section{Optimasi proses ekstrusi mi jagung}

Optimasi proses dilakukan untuk mendapatkan suatu proses optimum dari respon-respon yang dikehendaki. Kriteria atau parameter yang dipilih sebagai respon dalam optimasi proses mengikuti mutu utama dari pemasakan mi yaitu cooking loss, kekerasan waktu pemasakan, derajat pengembangan dan kehalusan atau elastisitas serta elongasi. Kriteria utama yang penting dimiliki oleh produk mi kering adalah cooking loss dan elongasi karena berkaitan dengan penerimaan atau tingkat kesukaan produk oleh konsumen. Sedangkan respon derajat gelatinisasi dipilih karena selain pengaruhnya terhadap sifat atau mutu fisik mi, tetapi juga berpengaruh terhadap sifat fungsional produk setelah proses ekstrusi yaitu kecepatan daya cerna pati (Mahasukhonthachat et al., 2010).

Penentuan proses optimum dengan RSM pada Design Expert 7.0 dilakukan dengan menetapkan parameter dengan nilai batas serta kepentingan (importance) berdasarkan kriteria produk yang dikehendaki. Parameter yang dioptimasi dengan nilai batas, dan kepetingan yang diproses menggunakan Design Expert 7.0 ditunjukkan pada Tabel 3. Program Design Expert 7.0 memberikan solusi berupa beberapa kondisi proses terpilih yang dianggap sesuai dengan kriteria dan pembatas yang telah ditentukan. Nilai desirability yang diberikan oleh Design Expert 7.0 pada proses optimasi ini ditunjukkan pada Tabel 4.

Terdapat empat kondisi proses yang diurutkan berdasarkan nilai desirability masing-masing kondisi proses. Nilai desirability yang mendekati 1 berada pada peringkat pertama sebagai kondisi proses yang direkomendasikan oleh program sebagai hasil optimasi. Nilai desirability yang semakin mendekati 1 berarti semakin tingginya kesesuaian proses optimasi dengan variabel respon untuk menghasilkan kondisi proses yang optimal. Tabel 4 menunjukkan kondisi proses optimum yang terpilih (selected) adalah kondisi proses dengan suhu $95^{\circ} \mathrm{C}$ dan kecepatan screw 100 rpm dengan prediksi nilai pada setiap respon antara lain cooking loss $10,11 \%$, elongasi $156,73 \%$, kekerasan 6252 gf dan derajat gelatinisasi $92,26 \%$, serta nilai desirability sebesar 0,954 atau $95,4 \%$.

\section{Hasil verifikasi proses optimum}

Salah satu keluaran dari proses optimasi dengan RSM adalah tabel prediksi yang menampilkan nilai respon dari kondisi proses yang terpilih. Prediksi nilai respon tersebut kemudian diverifikasi untuk mengetahui model dari program dapat memprediksi dengan baik. Nilai respon prediksi dari Design Expert 7.0 dibandingkan dengan nilai respon aktual yang diperoleh dari hasil analisis verifikasi.

Hasil verifikasi yang dilakukan beserta prediksi dan prediksi setiap respon dapat dilihat pada Tabel 5. Hasil prediksi nilai respon aktual memiliki karakteristik cooking loss 10,37\%, elongasi 143,78\%, kekerasan $60,43 \%$ dan derajat gelatinisasi $91,39 \%$. Nilai cooking loss dan kekerasan mi jagung Elos lebih tinggi dan memiliki nilai elongasi yang lebih rendah dari mi jagung hibrida Bisi-2 pada penelitian Muhandri et al. (2011).

Hal ini berarti bahwa mi jagung hibrida Bisi-2 dengan teknologi ekstrusi pada kondisi optimum suhu ekstruder $90^{\circ} \mathrm{C}$ dan kecepatan screw ekstruder 130 rpm lebih baik secara kualitas fisik dibandingkan mi jagung Elos pada kondisi optimum suhu ekstruder $95^{\circ} \mathrm{C}$ dan kecepatan screw ekstruder 100 rpm. Hal ini dikarenakan tepung jagung yang digunakan pada penelitian Muhandri et al. (2011) adalah tepung jagung yang lolos ayakan 100 mesh, sedangkan tepung jagung Elos yang digunakan pada penelitian ini adalah tepung jagung yang lolos ayakan 80 mesh. Muhandri et al. (2012) menjelaskan bahwa tepung jagung yang tidak lolos ayakan 100 mesh pada aplikasi pembuatan mi jagung sulit membentuk gel yang kuat jika tanpa adanya tekanan shear yang cukup dan berpengaruh terhadap tingkat gelatinisasi pati yang tidak serempak, sedangkan tingkat atau derajat gelatinisasi pati dapat berpengaruh terhadap mutu fisik mi yang dihasilkan.

Tabel 3. Kriteria dan pembatas pada penetapan proses optimasi dengan RSM

\begin{tabular}{lcccc}
\hline \multicolumn{1}{c}{ Parameter } & Tujuan & Batas Bawah & Batas Atas & Kepentingan \\
\hline Cooking loss (\%) & Minimum & 9,37 & 25,17 & 5 \\
Elongasi (\%) & In range & 102,37 & 179,85 & 4 \\
Kekerasan (gf) & In range & 3654,15 & 8744,60 & 4 \\
Derajat gelatinisasi (\%) & In range & 82,25 & 93,62 & 3 \\
\hline
\end{tabular}


Tabel 4. Nilai desirability pada kondisi proses yang diberikan oleh Design Expert 7.0

\begin{tabular}{cccccccc}
\hline No & Suhu $\left({ }^{\circ} \mathrm{C}\right)$ & $\begin{array}{c}\text { Kecepatan } \\
(\mathrm{rpm})\end{array}$ & $\begin{array}{c}\text { Cooking Loss } \\
(\%)\end{array}$ & $\begin{array}{c}\text { Elongasi } \\
(\%)\end{array}$ & $\begin{array}{c}\text { Kekerasan } \\
(\mathrm{gf})\end{array}$ & $\begin{array}{c}\text { Derajat Gelatinisasi } \\
(\%)\end{array}$ & Desirability \\
\hline 1 & 95 & 100 & 10,11 & 156,73 & 6252 & 92,26 & 0,954 \\
2 & 95 & 100 & 10,12 & 155,76 & 6276 & 92,38 & 0,953 \\
3 & 94 & 160 & 10,21 & 178,11 & 6605 & 92,10 & 0,947 \\
4 & 94 & 160 & 10,21 & 178,11 & 6602 & 92,08 & 0,947 \\
\hline
\end{tabular}

Tabel 5. Nilai prediksi dari program Design Expert 7.0 dan verifikasi hasil optimasi

\begin{tabular}{lcccccc}
\hline \multicolumn{1}{c}{ Response } & Prediction & 95\% Cl low & $\begin{array}{c}95 \% \text { Cl } \\
\text { high }\end{array}$ & $\begin{array}{c}\text { 95\% Pl low } \\
\text { Cooking loss (\%) }\end{array}$ & $\begin{array}{c}95 \% \text { Pl } \\
\text { high }\end{array}$ & Verification Result \\
\hline Elongasi (\%) & 10,11 & 6,57 & 13,64 & 2,42 & 17,79 & 10,37 \\
Kekerasan (gf) & 156,75 & 135,84 & 177,66 & 111,29 & 202,21 & 143,78 \\
Derajat gelatinisasi (\%) & 6261 & 5212 & 7290 & 3992 & 8510 & 6043 \\
\hline
\end{tabular}

Hasil verifikasi tersebut memenuhi $95 \%$ confident interval dan $95 \%$ prediction interval yang disediakan pada tabel prediksi oleh program Design Expert 7.0. Hal ini menunjukkan bahwa persamaan yang diperoleh dianggap cukup baik untuk menentukan proses optimum dan respon yang didapatkan

\section{KESIMPULAN}

Karakteristik tepung jagung varietas lokal Elos memiliki kadar amilosa sebesar $27,89 \%$ dari karbohidrat yang menunjukkan bahwa tepung Elos termasuk jenis pati sedang atau normal. Sifat gelatinisasi tepung Elos memiliki suhu awal gelatinisasi $73,55^{\circ} \mathrm{C}$ dan suhu gelatinisasi maksimum $91,05^{\circ} \mathrm{C}$. Kondisi proses optimum dengan variabel suhu dan kecepatan screw ekstruder yang dihasilkan pada optimasi proses menggunakan RSM dengan program Design Expert 7.0 ini adalah pada suhu $95^{\circ} \mathrm{C}$ dan kecepatan screw ekstruder $100 \mathrm{rpm}$.

Berdasarkan empat parameter yang digunakan sebagai respon pada mi jagung antara lain cooking loss, elongasi, kekerasan dan derajat gelatinisasi diperoleh hasil sebagai berikut: cooking loss $10,11 \%$, elongasi 156,73\%, kekerasan 6252 gf dan derajat gelatinisasi $92,26 \%$, serta nilai desirability sebesar 0,954 atau $95,4 \%$. Hasil tersebut sesuai dengan hasil verifikasi optimasi proses yang dilakukan karena nilai prediksi tidak jauh berbeda dengan nilai aktual hasil verifikasi yaitu berada dalam rentang confident interval dan prediction interval. Dengan demikian dapat disimpulkan bahwa hasil optimasi yang diperoleh sesuai dengan model yang diberikan oleh program. Tepung jagung Elos memiliki karakteristik (pasting properties) yang baik untuk digunakan sebagai bahan baku mi dengan teknologi ekstrusi sehingga dapat dipertimbangkan sebagai bahan baku mi non terigu (gluten free) dalam industri pangan.

\section{UCAPAN TERIMA KASIH}

Ucapan terima kasih disampaikan kepada Lembaga Pengelola Dana Pendidikan (LPDP) sebagai pemberi dana pada penelitian ini (tahun 2017-2018).

\section{DAFTAR PUSTAKA}

[AOAC] Association of Official Analytical Chemists 2012. Official Methods of Analysis of the Association of Official Analytical Chemist $19^{\text {th }}$ Edition. Association of Official Analytical Chemists. Washington DC.

Aydin E, Gocmen D. 2011. Cooking quality and sensorial properties of noodle supplemented with oat flour. Food Sci Biotechnol 20: 507-511. DOI: 10.1007/s10068-011-0070-1.

Budi FS, Hariyadi P, Budijanto S, Syah D. 2015. Effect of dough moisture content and extrusion temperature on degree of gelatinization and crystalinity of rice analogues. J Dev Sustain Agr 10: 91-100. DOI: 10.11178/jdsa.10.91.

Engelen A, Sugiyono, Budijanto S. 2015. Optimasi proses dan formula pada pengolahan mi sagu kering (Metroxylon sagu). Agritech 35: 359-367. DOI: 10.22146/agritech.9319.

Faridah DN, Ferdiaz D, Andarwulan N, Sunarti TC. 2014. Karakteristik sifat fisikokimia pati garut (Marantha arundinaceae). Agritech 34: 14-21. DOI: 10.22146/agritech.9517.

Indrianti N, Sholichah E, Darmajana DA. 2014. Proses pembuatan mi jagung dengan bahan baku tepung jagung 60 mesh dan teknik sheetingslitting. J Pangan 23: 256-267.

Kesarwani A, Chiang PY, Chen SS. 2016. Rapid visco analyzer measurements of japonica rice cultivars to study interrelationship between pas- 
ting properties and farming system. Int $\mathrm{J}$ Agron 2016: 1-6. DOI: 10.1155/2016/3595326.

Kongkiattisak P, Songsermpong S. 2012. Effect of temperature and velocity of drying air on kinetics, quality and energy consumption in drying process of rice noodles. Kasetsart $\mathrm{J}$ (Nat Sci) 46: 603-619.

Kusnandar F, Palupi NS, Lestari OA, Widowati S. 2009. Karakterisasi tepung jagung termodifikasi heat moisture treatment (HMT) dan pengaruhnya terhadap mutu pemasakan dan sensori mi jagung kering. J Pascapanen 6: 76-84.

Liu H, Xie F, Yu L, Chen L, Li L. 2009. Thermal processing of starch-based polymers. Prog Polym Sci 34: 1348-1368. DOI: 10.1016/j.progpolym sci.2009.07.001.

Liu Q. 2005. Understanding Starches and their Role in Foods. In: Cui SW, editor. Food Carbohydrates: Chemistry, Physical Properties and Applications.340. CRC Pres, Boca Raton FL.

Mahasukhonthachat K, Sopade PA, Gidley MJ. 2010. Kinetics of starch digestion and functional properties of twin screw extruded sorghum. J Cereal Sci 51: 392-401. DOI: 10.1016/j.jcs.201 0.02.008.

Muhandri T. 2012. Karakteristik Reologi Mi Jagung dengan Proses Ekstrusi Pemasak-Pencetak. [Disertasi]. Bogor: Fakultas Teknologi Pertanian, Institut Pertanian Bogor.

Muhandri T, Ahza AB, Syarief R, Sutrisno. 2011. Optimasi proses ekstrusi mi jagung dengan metode permukaan respon. J Teknol Industri Pangan 12: 97-104.

Muhandri T, Subarna. 2009. Pengaruh kadar air, $\mathrm{NaCl}$ dan jumlah passing terhadap karakteristik reologi mi jagung. J Teknol Industri Pangan 20: 71-77.
Muhandri T, Zulkhaiar H, Subarna, Nurtama B. 2012. Komposisi kimia tepung jagung varietas unggul lokal dan potensinya untuk pembuatan mi jagung menggunakan ekstruder pencetak. J Sains Terapan 2: 16-27.

Subarna, Muhandri T, Nurtama B. Firlieyanti AS. 2012. Peningkatan mi kering jagung dengan penerapan kondisi optimum proses dan penambahan monogliserida. J Teknol Industri Pangan 13: 146-152. DOI: 10.6066/jtip.2012.23.2.146.

Tam LM, Corke H, Tan WT, Li J, Collado LS. 2004. Production of bihon-type noodles from maize starch differing in amylose content. Cereal Chem 81: 475-480. DOI: 10.1094/CCHEM.200 4.81.4.475.

Tan FJ, Dai WT, Hsu KC. 2009. Changes in gelatinization and rheological characteristics of japonica rice starch induced by pressure/heat combinations. J Cereal Sci 49: 285-289. DOI: 10.1016/j.jcs.2008.11.006.

Wang N, Maximiuk L, Toews R. 2012. Pea starch noodles: Effect of processing variables on characteristics and optimisation of twin-screw extrusion process. Food Chem 133: 742-753. DOI: 10.1016/j.foodchem.2012.01.087.

Wang N, Warkentin TD, Vandenberg B, Bing DJ. 2014. Physicochemical properties of starches from various pea and lentil varieties, and characteristics of their noodles prepared by high temperature extrusion. Food Res Int 55: 119127. DOI: 10.1016/j.foodchem.2012.01.087.

Wu F, Meng Y, Yang N, Tao H, Xu X. 2015. Effect of mung bean starch on quality of rice noodles made by direct dry flour extrusion. LWT-Food Sci Technol 63: 1199-1205. DOI: 10.1016/j.Iwt. 2015.04.063. 